\title{
Benthic response to upwelling events off the SE Brazilian coast
}

\author{
Paulo Y. G. Sumida ${ }^{1, *}$, Marcos Y. Yoshinaga ${ }^{1}$, Áurea M. Ciotti ${ }^{2}$, Salvador A. Gaeta ${ }^{1}$ \\ ${ }^{1}$ Laboratório de Dinâmica Bêntica, Instituto Oceanográfico da Universidade de São Paulo CEP: 05508-120, São Paulo, Brazil \\ ${ }^{2}$ UNESP Campus do Litoral Paulista, Praça Infante Dom Henrique $\mathbf{s} / n^{\circ}$, São Vicente SP 11330-900, Brazil
}

\begin{abstract}
The main aim of the present study was to evaluate and compare temporal responses of the benthos in 2 continental shelf areas (Cabo Frio and Ubatuba) off the SE Brazilian coast. In Cabo Frio $\left(23^{\circ} \mathrm{S}, 42^{\circ} \mathrm{W}\right)$, the western boundary coastal upwelling of the South Atlantic Central Water (SACW) enhances primary productivity, potentially increasing food supply to the benthic communities via sinking of particulate organic carbon (POC). In contrast, POC fluxes in Ubatuba $\left(23^{\circ} \mathrm{S}, 45^{\circ} \mathrm{W}\right)$ are expected to be comparatively lower because SACW remains subsurface. We analyzed the temporal and spatial input of phytodetritus (concentration of chlorophyll $a$ in sediments) and the benthic microbial biomass (estimated by ATP-based carbon content in sediments). Median surface chlorophyll concentration was computed for all daily available SeaWiFS images (from 2001 and 2002) to follow chlorophyll a inputs. All parameters used to investigate benthic responses in the study areas showed consistently higher values in Cabo Frio than in Ubatuba. The results showed that benthic response to upwelling may last months, fueling the microbial communities in the Cabo Frio region.
\end{abstract}

KEY WORDS: Benthic-pelagic coupling $\cdot$ Benthic microbial response $\cdot$ SE Brazilian continental shelf Resale or republication not permitted without written consent of the publisher

\section{INTRODUCTION}

The input of organic material to the seafloor strongly depends on the biological production occurring in the euphotic zone, and the degree to which vertical sinking of phytoplankton aggregates and faecal pellets successfully reach the bottom. On average, 25 to $50 \%$ of the primary productivity reaches the seabed in coastal areas, whereas only about $1 \%$ is delivered to the deep sea (Suess 1980). The sinking of particulate organic carbon (POC) is subjected to seasonal variations due to the phytoplanktonic annual productivity cycle (Pfannkuche et al. 2000). As a consequence, export inputs to the benthic system can be episodic. This pulsed organic material delivered to the sediments has important consequences for the activity and structure of bottom communities in terms of abundance (see Gooday \& Turley 1990), biomass (Duineveld et al. 2000, Brown et al. 2001) and seasonal cycles of reproduction, growth and recruitment of invertebrates (Tyler 1988, Sumida et al. 2000). Sediment biogeochemical processes transform the deposited material and return them (e.g. nutrients) to the water column and, as a consequence, benthic-pelagic coupling occurs (Graf 1992, Soetaert et al. 2000).

In the last 2 decades, several studies have focused on the temporal variability of the coupling between benthos and water column processes. These studies have reported a rapid reaction of the benthic microbial community to organic inputs through fast increases in biomass (Soltwedel 1997). Responses of unicellular organisms tend to mirror the prevailing food conditions rather than long-term averages of available food (Lavaleye et al. 2002). However, this seems not to be entirely true for metazoans (e.g. Gooday \& Turley 1990, Graf 1992). The investigation of benthic-pelagic coupling processes through a benthic view is one of the tools used to understand the organic carbon flow and biogeochemical cycles in the ocean. 
The present study is part of the DEPROAS (SW Atlantic Continental Shelf Ecosystem Dynamics) project, which aimed to investigate the influence of the cold and nutrient-rich South Atlantic Central Water (SACW) on the marine ecosystem. We compared the benthic responses in Cabo Frio, where there is a seasonal, Ekman-driven coastal upwelling of the SACW during the summer months (Miranda 1982, Matsuura 1986), with Ubatuba, where the SACW is found in summer at shallow subsurface depths ( $10 \mathrm{~m})$ (CastroFilho et al. 1987). This seasonal physical pattern in the South Brazilian Bight (SBB) seems to govern a marked biological productivity in the area.

In Cabo Frio, phytoplankton biomass ranges from 5 to $12 \mathrm{mg}$ chl a m${ }^{-3}$ during the summer months (Gonzalez-Rodriguez 1991), with extreme reported levels reaching $25.5 \mathrm{mg}$ chlorophyll a (chl a) $\mathrm{m}^{-3}$ (Moser \& Gianesella-Galvão 1997). The latter levels are comparable to values from Antarctica ( 25 to $35 \mathrm{mg} \mathrm{chl} \mathrm{a} \mathrm{m}^{-3}$ ), where primary productivity is concentrated in only 1 period of the year (Karl et al. 1996). In Ubatuba, on the other hand, mean chlorophyll values are lower $(0.67$ to $2.77 \mathrm{mg} \mathrm{chl} \mathrm{a} \mathrm{m}^{-3}$ ), even though there is an enhancement of primary production during the summer months (Aidar et al. 1993).

The increase in primary production seems to drive some important biological patterns of benthic inhabitants. Ventura et al. (1997) reported strong correlations between the gametogenic cycle of the sea-star Astropecten brasiliensis and the intrusion of SACW in Cabo Frio. These data highlight the influence of SACW in the SBB ecosystem, promoting the enhancement of biological production in the pelagic system (Valentin et al. 1987, Silveira et al. 2000), and a subsequent transfer to the benthic assemblages.

Our goal is to assess the response of the benthic microbial communities (estimated from sediment C-ATP content) to the temporal and spatial input of phytodetritus (concentration of chl $a$ in sediments) as a marker for labile organic matter (Graf 1989, Sun et al. 1991, Boon \& Duineveld 1998, Danovaro et al. 1999, Pfannkuche et al. 2000) in areas with contrasting primary production regimes.

\section{MATERIALS AND METHODS}

Study site at the SE Brazilian continental shelf. The SE Brazilian Bight (SBB, 23 to $28^{\circ} \mathrm{S}$ ) is influenced by 3 water masses: the Tropical Water (TW, T>20 ${ }^{\circ} \mathrm{C}$ and $\mathrm{S}>36.40)$, the SACW $\left(T<20^{\circ} \mathrm{C}\right.$ and $\left.\mathrm{S}<36.40\right)$, and the Coastal Water $(\mathrm{CW}$, a low-salinity water resulting from the dilution of oceanic water by fresh water input from small to medium-sized estuaries along SBB) (Campos et al. 1996, 2000, Silveira et al. 2000). According to
Castro \& Miranda (1998), the intrusion of the SACW in SBB is related to meanders and eddies formed by the Brazil Current $(\mathrm{BC}$, the interaction of TW and the SACW). Off Cabo Frio $\left(23^{\circ} \mathrm{S}\right.$ to $\left.42^{\circ} \mathrm{W}\right)$, Rio de Janeiro State, the SBB is characterized by a relatively narrow shelf ( $\sim 50 \mathrm{~km}$ in length), with an abrupt change in coastline direction (from NE-SW in the northern portion to $\mathrm{E}-\mathrm{W}$ in the southern portion). Under prevailing N-NE winds, surface water moves offshore (via Ekman transport), resulting in the upwelling of SACW, which occurs more commonly during the summer (Silveira et al. 2000). The coastal upwelling is inhibited when southern cold fronts (S-SW winds) reach the area (Valentin et al. 1987). Despite its seasonal nature, upwelling events are not only restricted to summer months (Matsuura 1986), being activated when upwelling winds are favorable.

Off Ubatuba $\left(24^{\circ} \mathrm{S}\right.$ to $\left.45^{\circ} \mathrm{W}\right)$, Sao Paulo State, the extension of the shelf is much larger, reaching approximately $120 \mathrm{~km}$. A strong summer thermocline (20 to $50 \mathrm{~m}$ depth) is formed by the intrusion of SACW below the CW. During the winter, SACW retreats towards the slope (Castro-Filho et al. 1987).

Sampling and methodological approaches for chl a and microbial biomass. Sampling was undertaken during the BENTHOS cruises (within the DEPROAS project) in July 2001, February 2002 and September 2002, on board the RV 'Prof. W. Besnard' (Oceanographic Institute/University of Sao Paulo) (Table 1). Sediment samples were collected with a spade box corer (area $=0.09 \mathrm{~m}^{2}$; total volume $\left.=45 \mathrm{l}\right)$ at depths of 40, 100, 250 and $500 \mathrm{~m}$ off Cabo Frio (Stns CF40, CF100, CF250 and CF500) and at depths of 40 and $100 \mathrm{~m}$ off Ubatuba (Stns UB40 and UB100) (Fig. 1). Deep-water sampling ( $>250 \mathrm{~m}$ ) was prevented during the second survey owing to the loss of the box corer. After retrieval, each box was subsampled with a $10 \mathrm{~cm}$ diameter plexiglass corer. The corers were sliced in vertical intervals ( 0 to 1,1 to 2,2 to 3,3 to 4,4 to 6,6 to 8 and 8 to $10 \mathrm{~cm}$ ) for chl $a$, ATP and grain size analyses.

Sediment chl a samples were frozen at $-20^{\circ} \mathrm{C}$ and concentrations were measured spectrophotometrically (absorbance read at 430 and $665 \mathrm{~nm}$ ) in the laboratory (Plante-Cuny 1978) after extraction with $100 \%$ acetone. Six replicate ATP samples were extracted for each sediment horizon with $\mathrm{H}_{3} \mathrm{PO}_{4}$ on board and frozen at $-20^{\circ} \mathrm{C}$ for subsequent analysis. The microbial biomass was estimated though the quantification of particulate Adenosine 5' Triphosphate (P-ATP) described by Karl (1993) (see also Karl \& Dobbs 1998) and converted to carbon biomass using a constant ratio carbon:ATP of 250:1 (Karl 1980). Sediment grain size was measured using a Malvern laser diffraction sediment analyzer. Statistical analyses were performed using a Kruskall-Wallis, non-parametric test. 
Table 1. Stations sampled during Project DEPROAS in Cabo Frio and Ubatuba (summer 2001, winter 2001, summer 2002 and spring 2002)

\begin{tabular}{|lrcrc|}
\hline Cruise & Stn & $\begin{array}{c}\text { No. of box } \\
\text { corer samples }\end{array}$ & $\begin{array}{c}\text { Depth } \\
\text { (m) }\end{array}$ & Latitude (S), Longitude (W) \\
\hline Cabo Frio - & CF 40 & 1 & 37 & $22^{\circ} 58.43^{\prime}, 42^{\circ} 03.34^{\prime}$ \\
winter 2001 & CF 40 & 1 & 37 & $22^{\circ} 58.43^{\prime}, 42^{\circ} 03.34^{\prime}$ \\
& CF 100 & 1 & 102 & $23^{\circ} 04.50^{\prime}, 42^{\circ} 00.90^{\prime}$ \\
& CF 100 & 2 & 103 & $23^{\circ} 00.50^{\prime}, 42^{\circ} 00.90^{\prime}$ \\
& CF 250 & 2 & 247 & $23^{\circ} 46.10^{\prime}, 41^{\circ} 42.70^{\prime}$ \\
& CF 500 & 1 & 470 & $23^{\circ} 48.80^{\prime}, 41^{\circ} 41.30^{\prime}$ \\
Ubatuba - & UB 100 & 2 & 110 & $24^{\circ} 20.00^{\prime}, 44^{\circ} 51.60^{\prime}$ \\
winter 2001 & UB 40 & 2 & 37 & $23^{\circ} 42.30^{\prime}, 45^{\circ} 01.60^{\prime}$ \\
Ubatuba - & UB 40 & 2 & 37 & $23^{\circ} 42.30^{\prime}, 45^{\circ} 01.60^{\prime}$ \\
summer 2002 & UB 100 & 2 & 103 & $24^{\circ} 20.00^{\prime}, 44^{\circ} 51.60^{\prime}$ \\
Cabo Frio - & CF 40 & 2 & 35 & $22^{\circ} 58.56^{\prime}, 42^{\circ} 03.19^{\prime}$ \\
summer 2002 & CF 100 & 2 & 103 & $23^{\circ} 04.05^{\prime}, 42^{\circ} 00.90^{\prime}$ \\
Ubatuba - & CF 250 & 0 & 235 & Box corer lost $^{\prime}$ \\
Spring 2002 & UB 40 & 2 & 36 & $23^{\circ} 42.30^{\prime}, 45^{\circ} 01.60^{\prime}$ \\
Cabo Frio - & CF 40 & 2 & 100 & $24^{\circ} 20.00^{\prime}, 44^{\circ} 51.60^{\prime}$ \\
spring 2002 & CF 100 & 2 & 40 & $22^{\circ} 58.50^{\prime}, 42^{\circ} 03,20^{\prime}$ \\
& CF 250 & 3 & 100 & $23^{\circ} 04.50^{\prime}, 42^{\circ} 00.90^{\prime}$ \\
& CF 500 & 2 & 500 & $23^{\circ} 46.10^{\prime}, 41^{\circ} 42.70^{\prime}$ \\
& & & $23^{\circ} 48.80^{\prime}, 41^{\circ} 41.30^{\prime}$ \\
\hline
\end{tabular}

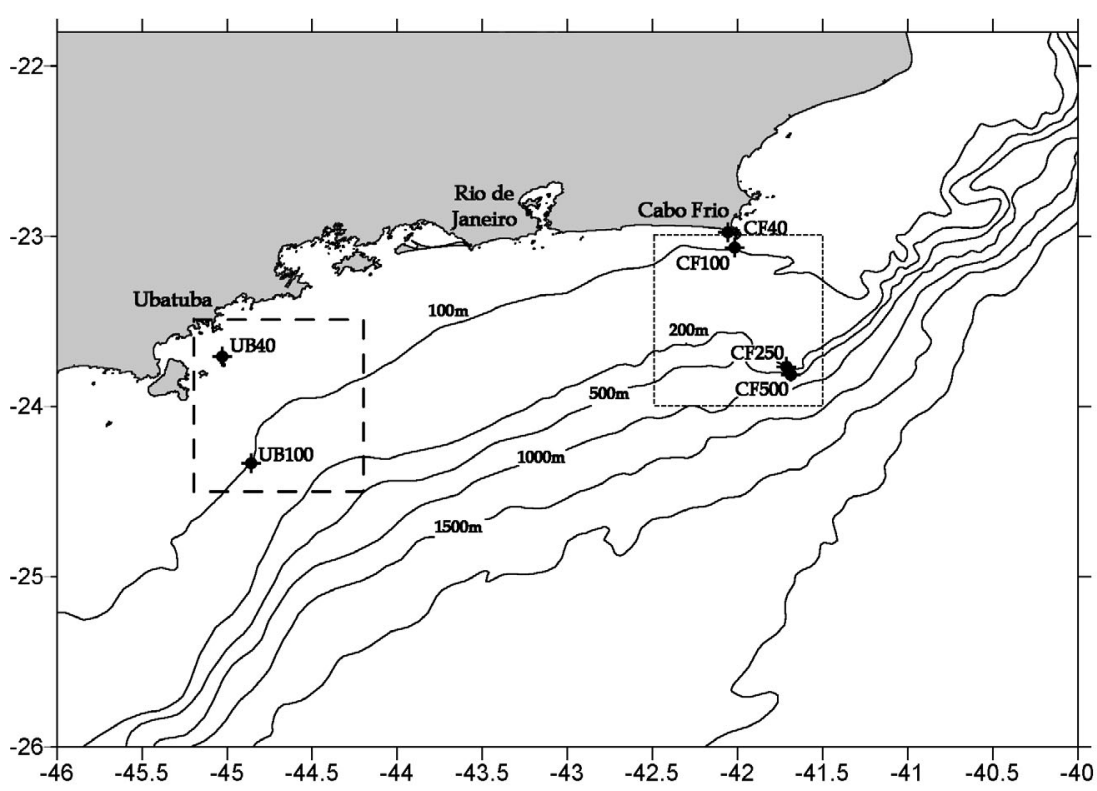

Fig. 1. Sampling stations off the SE Brazilian coast. Squares represent areas where median chlorophyll values were obtained from SeaWiFS data. UB40 and UB100: Ubatuba stations at 40 and $100 \mathrm{~m}$ depth, respectively; CF40, CF100, CF250 and CF500: Cabo Frio stations at 40, 100, 250 and $500 \mathrm{~m}$ depth, respectively

Sea surface images from SeaWiFS satellite and chlorophyll anomalies. We used 2 yr of daily surface maps of estimated chlorophyll concentration using the data from the SeaWiFS sensor. Two areas were arbitrarily chosen over the sampling points (Fig. 1), at Ubatuba (latitudes between $23^{\circ} 30^{\prime}$ and $24^{\circ} 30^{\prime} \mathrm{S}$, and longitudes between $44^{\circ} 12^{\prime}$ and $45^{\circ} 12^{\prime} \mathrm{W}$ ) and Cabo Frio (latitudes between $23^{\circ} 00^{\prime}$ and $24^{\circ} 00^{\prime} \mathrm{S}$, and longitudes between $41^{\circ} 30^{\prime}$ and $44^{\circ} 00^{\prime} \mathrm{W}$ ). The idea was to compute a median value for each area for the $2 \mathrm{yr}$ period and to use the daily values to estimate a time series of chlorophyll 'anomalies'. This was made in order to emphasize the variability of chlorophyll inputs rather than their absolute values, as the regions present many distinct particularities, which include different depths, different oceanographic processes, and different background values of chlorophyll concentration. Note that in this approach, we are assuming that the variability in chlorophyll concentration at the surface covaries well with that from depthintegrated chlorophyll values.

Maps of surface chlorophyll were produced as follows: (1) Daily HRPT SeaWiFS images $(1 \mathrm{~km}$ resolution at nadir) were acquired from DAAC (Distributed Active Archive Center) from NASA as Level 1A. (2) Daily meteorological data, also acquired at DAAC, were used to process Level 1A images to Level 2, from which surface chlorophyll concentration was estimated using the global oc2 algorithm version 4 . The values estimated using this algorithm agree well with in situ data (Á. M. Ciotti et al. unpubl. data). Chlorophyll concentrations of less than 0.01 or greater than $32 \mathrm{mg} \mathrm{m}^{-3}$ were excluded because the general upper limit for the oc2 algorithm of $64 \mathrm{mg} \mathrm{m}^{-3}$ is unrealistic for the study area (Gonzalez-Rodriguez 1991, Moser \& Gianesella-Galvão 1997), and only observed in the images for pixels close to cloudy areas or land. The products were mapped to a cylindrical projection and the values from the 2 areas were isolated (Cabo Frio and Ubatuba). Within each area, sub-regions were analyzed separately, depending on the depth ranges (from 5 to $200 \mathrm{~m}$ ). The median chlorophyll concentration was computed for all daily available images in which the coverage (i.e. pixels containing data) was $>50 \%$. A 'global' median value for each sub-area was computed for 2001 and 2002, and used to estimate a time series of chlorophyll 'anomalies', to emphasize the variability of chlorophyll inputs rather than their absolute values. 


\section{RESULTS}

\section{Temporal variability of $\mathrm{chl} a$ inventories}

Sedimentary chl a inventories for the first $10 \mathrm{~cm}$ of the sediment column ranged from 0.8 to $10.2 \mu \mathrm{g} \mathrm{g}^{-1}$. Overall, values at Cabo Frio were higher than those found in Ubatuba (Figs. 2 \& 3). Values at the $100 \mathrm{~m}$ station in Cabo Frio (CF100) were the highest in all periods (Fig. 2), ranging from 3.4 (spring 2002) to $10.2 \mathrm{\mu g} \mathrm{g}^{-1}$ (winter 2001). In contrast, the deepest stations, CF250 and CF500, sampled in winter 2001 and spring 2002, showed the lowest chl a concentrations (0.8 to $1.3 \mu \mathrm{g} \mathrm{g}^{-1}$ ) (Figs. 2 \& 3). At Stn CF250, almost no difference was found between winter and spring, but at CF500, values in spring were 1.6 greater than in winter. Surprisingly, Cabo Frio sediments showed higher concentrations of chl a in the winter of 2001, when sedimentary chl a values reached a peak at Stns CF40 and CF100 (Fig. 2). Values from winter 2001 at Stns CF40 and CF100 were 1.7 times greater than those found during the summer of 2002 and more than 2.6 times (mean value for both stations) higher in spring 2002.

No marked temporal changes in sedimentary chl a inventories were found in Ubatuba. Values ranged from 0.9 to $2.8 \mu \mathrm{g} \mathrm{g}^{-1}$, with slight increases in the summer of 2002 at Stns UB40 and, particularly, UB100 (mean values 1.4 and 1.7 times greater than winter and spring, respectively) (Fig. 3). Stn UB40 showed the highest values in all periods, ranging from $2.4 \mu \mathrm{g}$ $\mathrm{g}^{-1}$ during winter to $2.8 \mu_{\mathrm{g} \mathrm{g}}{ }^{-1}$ in summer. The lowest values were found at Stn UB100 in spring $2002\left(0.9 \mu \mathrm{g} \mathrm{g}^{-1}\right)$. In the summer and spring of 2002, Stn UB40 presented values comparable to those found for the same periods and depth at Cabo Frio (Figs. 2 \& 3).

The concentration of chl $a$ in sediments of both areas seems to mirror the surface chl a anomalies monitored by SeaWiFS satellite data (Figs. 2 \& 3). Large anomalies occurred at Cabo Frio, with higher peaks in spring 2001 and summer 2002, just when the upwelling events are more common. In Ubatuba, the intensity of anomalies was much lower (Fig. 3).

\section{Sediment microbial biomass dynamics in response to organic matter input regimes}

Sediment microbial biomass inventories ranged from 283.4 to $5171.7 \mu \mathrm{g} \mathrm{C}$ $\mathrm{g}^{-1}$. Cabo Frio showed high biomass values, particularly in summer 2002, when a conspicuous peak was detected at Stns CF40 and CF100 (Fig. 4). A 4fold increase in biomass at Stns CF40 and CF100 was observed from winter to summer (Fig. 4). Spring 2002 inventories at Stn CF100 were nearly double
Fig. 3. Chl a inventories (bars) and sea-surface chlorophyll anomalies (lines) from Ubatuba in 2001 and 2002. Julian Days are summed for both years 


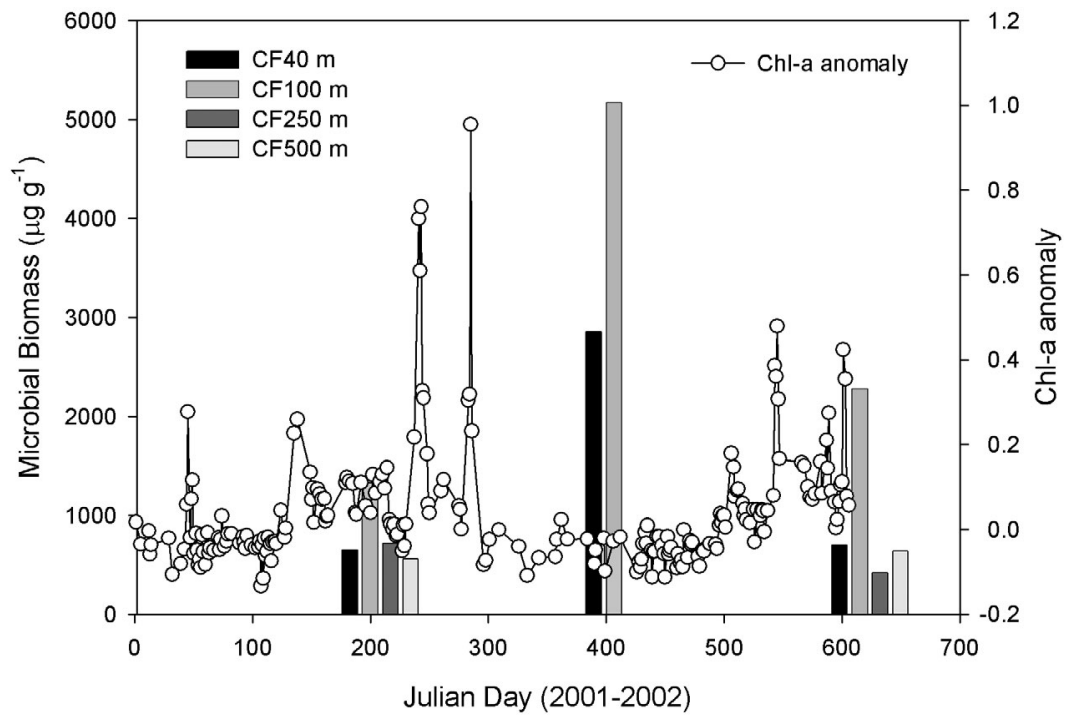

Fig. 4. Microbial biomass inventories (bars) and sea-surface chlorophyll anomalies (lines) from Cabo Frio in 2001 and 2002. Julian Days are summed for both years

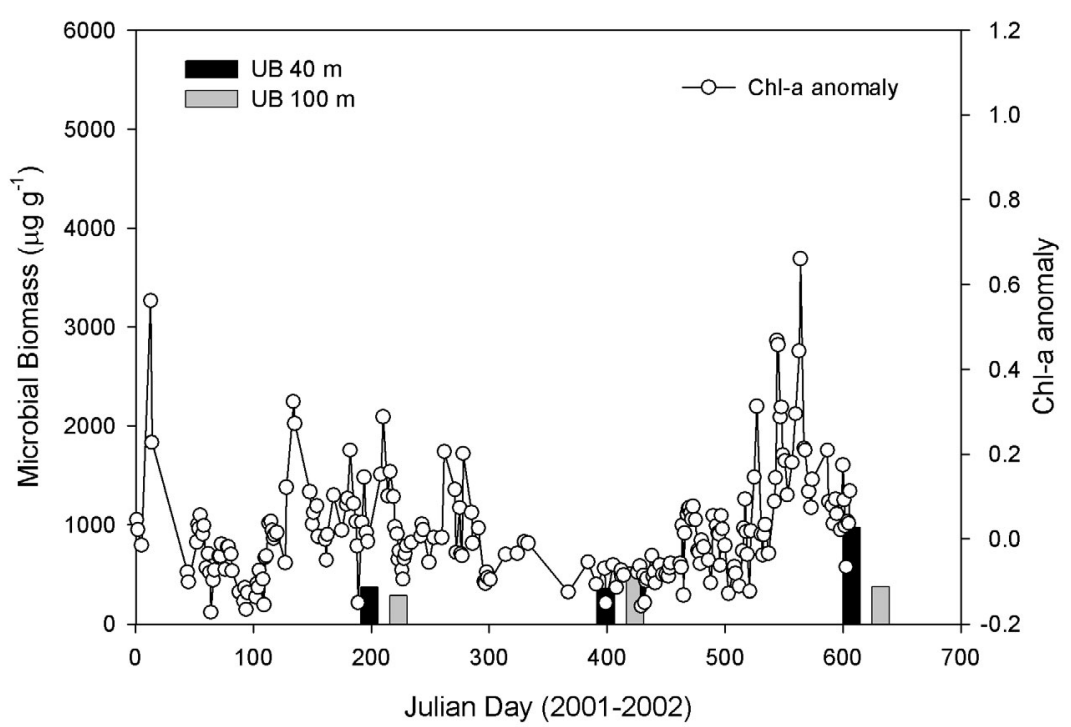

Fig. 5. Microbial biomass inventories (bars) and sea-surface chlorophyll anomalies (lines) from Ubatuba in 2001 and 2002. Julian Days are summed for both years

those of winter 2001. Besides, values from spring were even much lower than those in summer (Fig. 4). Stns CF250 and CF500 did not show pronounced differences between winter 2001 and spring 2002, comprising the lowest values observed in the area, except in winter for Stn CF250 (Fig. 4). Stn CF100 was the most influenced by the seasonality of the coastal upwelling off Cabo Frio waters, with high microbial biomass values in summer $2002\left(5171.7 \mu \mathrm{g} \mathrm{C} \mathrm{g}^{-1}\right)$, and progressively decreasing numbers in spring $2002\left(2277.9 \mathrm{\mu g} \mathrm{C} \mathrm{g}^{-1}\right)$ and winter 2001 (1330.9 $\mu \mathrm{C} \mathrm{g} \mathrm{g}^{-1}$ ).

In Ubatuba, where no clear temporal changes were observed (Fig. 5), values were low during all the studied periods. However, in general, larger amounts of sedimentary chl a corresponded to a larger microbial biomass (Figs. 2 to 5 ). The highest microbial biomass was found in spring 2002 at Stn UB40 (973.6 $\mathrm{\mu g} \mathrm{C} \mathrm{g}^{-1}$ ) and the lowest at UB100 in winter $2001\left(283.4 \mu \mathrm{C} \mathrm{g}^{-1}\right)$ (Fig. 5). Samples collected at Stn UB100 presented values 2 times higher in summer 2002 than in winter 2001 (Fig. 5).

Surface chl a anomalies showed clear differences between the study areas, with larger anomalies in Cabo Frio, except in spring 2002, when values at Ubatuba were higher (Figs. 2 \& 3). During this period, microbial biomass was 2.6 times greater than the other 2 periods analyzed (UB40, Fig. 5).

\section{DISCUSSION}

Our results suggest the enhanced primary productivity on the Cabo Frio coastal upwelling system is reflected in the sediments by a high microbial biomass and labile organic matter content (i.e. sedimentary chl a concentration), when compared with Ubatuba (Figs. 2 \& 5). The phytoplanktonic production in the euphotic zone off Cabo Frio is more than 5fold higher than that found off Ubatuba (Gonzalez-Rodriguez 1991, Aidar et al. 1993). Part of this organic material $(\mathrm{OM})$ is delivered to the benthos, establishing a tight benthicpelagic coupling in the area. Mahiques et al. (2002) pointed out that the deposition of organic matter from the pelagic system is more noticeable in Cabo Frio than other shelf areas of the SBB. Our findings also suggest that the upwelling events in Cabo Frio have a greater impact at a depth around $100 \mathrm{~m}$. Despite the seasonal nature of the upwelling in Cabo Frio, non-seasonal events may also trigger the upwelling, firing a series of benthic ecological responses, particularly in relation to the microbial communities. 


\section{Temporal changes of microbial biomass and sedimentary chl a in Ubatuba}

Temporal changes in the benthic microbial biomass and sedimentary chl a were not observed in Ubatuba. However, slight differences in these parameters probably indicate that shelf circulation may play a role in benthic dynamics. High values were found at Stn UB40, which might be related to the input of terrestrial OM to the benthic system. Furtado \& Mahiques (1990) described the importance of the rainy season (summer) for the transport of sediments and OM by the coastal water (CW) to the inner shelf ( 50 $\mathrm{m}$ depth). At midshelf depths, SACW advection creates conditions for a relatively high subsurface primary production, mainly during summer (Aidar et al. 1993). This can be seen in Fig. 3, where we observed a peak in microbial biomass and sedimentary chl $a$ at Stn UB100 (summer 2002), which was probably not apparent in the chl a anomaly values due to its sub-superficial nature.

Surface chl a anomalies were much lower in Ubatuba than Cabo Frio, despite the observation of some pulsed events, particularly in spring 2002 (Figs. 3 \& 5). The parameters used as a proxy to assess benthic community status did not respond temporally and they may be of minor importance to the benthic fauna structure in Ubatuba.

\section{Benthic responses to upwelling events in Cabo Frio}

According to Suess (1980), the coupling of benthic and pelagic systems mainly depends on depth, so we would expect a high deposition and concentration of phytodetritus at shallower stations. This was observed in Ubatuba, but not in Cabo Frio. The low values of sedimentary chl $a$ and benthic microbial biomass at Stn CF40 could be explained by the grain size, since coarser sediments do not allow retention of organic matter (Köster \& Meyer-Reil 2001). In Cabo Frio sediments, no significant differences in microbial biomass and chl a were found between samples from Stns CF40, CF250 and CF500 ( $p>0.05$ ). Only CF100 showed higher levels of such parameters $(p<0.01)$ within and among sampling periods (Figs. $2 \& 4$ ).

This trend could be related to the sinking trajectories of POC and hydrodynamics, as reported by Deuser (1986) and Siegel \& Deuser (1997) for the deep oceans. This is an important issue in the Cabo Frio area, where upwelling plumes are commonly found advancing offshore due to Ekman transport. Hence, it would be expected to find higher sedimentation rates at Stn CF100, agreeing with the higher standing stock of microfauna at this depth, where the concentration of sedimentary chl a was also conspicuous and muddy sediments dominate.
Data on abundance and distribution of nematodes corroborate our results in Cabo Frio, showing significant discrepancies between CF40 and CF100 (T. N. Corbisier pers. comm.). Furthermore, the benthic megafauna collected concomitantly during all sampling periods showed similar distribution, with higher standing stock developing around the $100 \mathrm{~m}$ isobath (De Léo 2003). Thus, there is a strong evidence of organic enrichment in CF100 sediments, which was significantly different from the others stations, in all periods, and is certainly related to the local coastal upwelling regime.

Surprisingly, the chl a inventories at Cabo Frio were higher in winter 2001 than during the summer and spring of 2002. This temporal uncoupling could be interpreted as a consequence of a high production in the euphotic zone. We speculated that this trend appeared as a result of the observed sea surface anomaly in winter 2001 (Figs. 2 \& 4). This fact also confirms the episodic nature of the Cabo Frio upwelling, which can be activated when winds are favorable, regardless of the time of year (Miranda 1982, Matsuura 1986, Campos et al. 2000, Silveira et al. 2000). However, the results did not corroborate the microbial biomass inventories for the same period (Figs. $2 \& 4$ ). Surface chl a positive anomalies also occurred in summer and late spring 2002, with even greater intensity. However, a lapse of time must be considered when evaluating benthic community responses to OM input (Graf 1989, Rudnick 1989).

High zooplanktonic grazing rates owing to phytoplankton blooming are thought to exist in the area (Valentin \& Moreira 1978, Kiørboe 2003). In this scenario, a consistent planktonic food web develops and a conspicuous deposition of faecal pellets, rather than phytoplankton cells, occurs (Lopes et al. 1999, Valentin \& Monteiro-Ribas 1993). In fact, observations made using an underwater camera during the summer sampling showed no phytoplankton aggregates (i.e. marine snow), suggesting that microbial loop might play an important role in diminishing the deposition of phytodetritus to the benthos (Kiørboe 2003).

Alternatively, since phytodetritus reached the bottom, the competition of microbenthic organisms with mega- and macrobenthos could favor larger fauna, which can respond through a rapid uptake, certainly influencing the initial burial of POC into sediment deposits (Webb \& Montagna 1993, Josefson et al. 2002). There appears to be a delay of a week between a depositional event of phytodetritus and the microbial community response (Graf 1989, Pfannkuche 1993, Soltwedel 1997, Raghukumar et al. 2001, Fontanier et al. 2003). Considering the surface chl a-positive anomalies found during summer 2002, a time lag between blooming, POC flux and community response would be expected (Fig. 6). Our findings suggest that phy- 
Fig. 6. Hypothetical model of phytodetritus input from the pelagic system coupled to the response of benthic microbial communities in Cabo Frio sediments. Note that a high microbial biomass may be sustained for at least $4 \mathrm{mo}$, even if no major upwelling event occurs

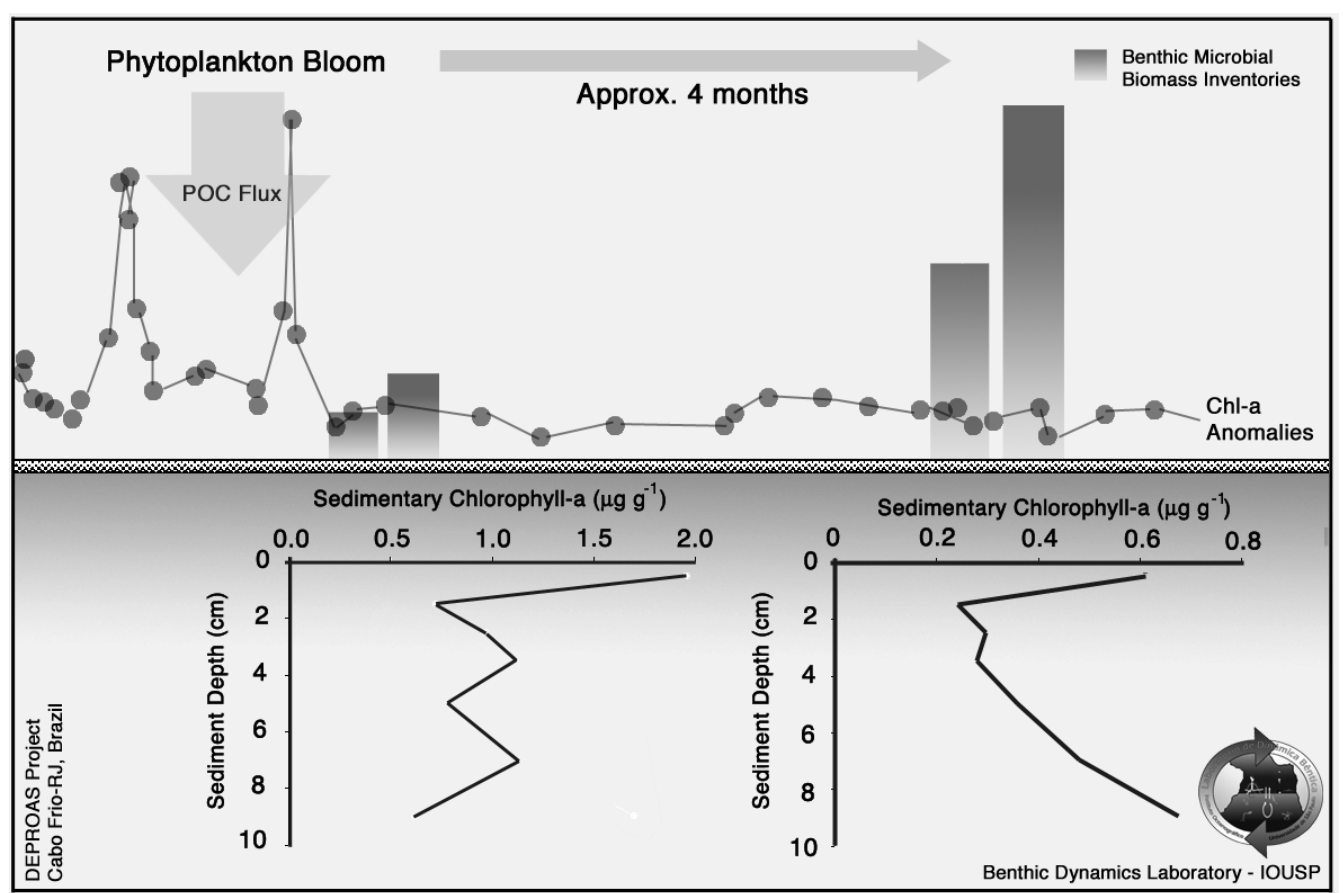

todetritus may last months in the sediments of Cabo Frio, probably fueling macrobenthic communities (Boon et al. 1998). Macrofauna is likely to depend on the input of fresh algal matter for its growth and reproduction (Cristensen \& Kanneworff 1985). However, other taxa may rely on more altered organic material, such as faecal pellets or OM in varying degrees of decay (Fontanier et al. 2003). Peaks in microbial biomass were observed in Cabo Frio 4 mo after a major upwelling event (Fig. 4). These microbial communities could enrich the quality of OM (Danovaro et al. 1993), being available as a food source to the benthic fauna between upwelling events (Fig. 6).

Acknowledgements. The authors are grateful for the financial support of FAPESP (Fundação de Amparo à Pesquisa do Estado de São Paulo-Grants 01/00165-2 to P.Y.G.S., 02/04209-7 to M.Y.Y., 01/00126-7 and 01/00125-0 to A.M.C.), FINEP (Financiadora de Estudos e Projetos) and CNPq/ PRONEX (Conselho Nacional de Desenvolvimento Científico e Tecnlógico, Brazilian Government), who supported the DEPROAS project. We also thank NASA, DAAC and the SeaWiFS Project for data and software.

\section{LITERATURE CITED}

Aidar E, Gaeta SA, Gianesella-Galvão SMF, Kutner MBB, Teixeira C (1993) Ecossistema costeiro tropical: nutrientes

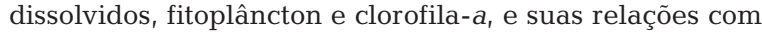
as condições oceanográficas na região de Ubatuba. Publ Esp Inst Oceanogr 10:9-43

Boon AR, Duineveld GCA (1998) Chlorophyll a as a marker for bioturbation and carbon flux in southern and central North Sea sediments. Mar Ecol Prog Ser 162:33-43
Boon AR, Duineveld GCA, Berghuis EM, Weele JA (1998) Relationships between benthic activity and the annual phytopigment cycles in near-bottom water and sediments in the southern North Sea. Estuar Coast Shelf Sci 46:1-13

Brown CJ, Lambshead PJD, Smith CR, Hawkins LE, Farley R (2001) Phytodetritus and the abundance and biomass of abyssal nematodes in the central, equatorial Pacific. DeepSea Res I 48:555-565

Campos EJD, Ikeda Y, Castro-Filho BM, Gaeta SA, Lorenzzetti JA, Stevenson MR (1996) Experiment studies circulation in the western South Atlantic. EOS Trans Am Geophys Union 77:253-259

Campos EJD, Velhote D, Silveira ICA (2000) Shelf break upwelling driven by Brazil Current cyclonic meanders. Geophys Res Lett 27:751-754

Castro BM, Miranda LB (1998) Physical oceanography of the Western Atlantic Continental Shelf located between $4^{\circ} \mathrm{N}$ and $34^{\circ} \mathrm{S}$. In: Robinson AR, Brink KH (eds) The sea, Vol 11. John Wiley \& Sons, New York, p 209-251

Castro-Filho BM, Miranda LB, Miyao SY (1987) Condições hidrográficas na plataforma continental ao largo de Ubatuba: variações sazonais e em média escala. Bolm Inst Oceanogr 35:135-151

Cristensen H, Kanneworff E (1985) Sedimenting phytoplankton as major food source for suspension and deposit feeders in the Øresund. Ophelia 24:223-244

Danovaro R, Fabiano M, Della Croce N (1993) Labile organic matter and microbial biomass in deep-sea sediments (eastern Mediterranean Sea). Deep-Sea Res I 40:953-965

Danovaro R, Dinet A, Duineveld GCA, Tselepides A (1999) Benthic response to particulate fluxes in different trophic environments: a comparison between the Gulf of LionsCatalan Sea (western-Mediterranean) and the Cretan Sea (eastern-Mediterranean). Prog Oceanogr 44:287-312

De Léo FC (2003) Estrutura e dinâmica da fauna bêntica em regiões da plataforma e talude superior do Atlântico Sudoeste. MSc thesis, University of São Paulo

Deuser WG (1986) Seasonal and interannual variations in 
deep-water particle fluxes in the Sargasso Sea and their relation to surface hydrography. Deep-Sea Res 33:225-246

Duineveld GCA, Tselepides A, Witbaard R, Bak RPM, Berghuis EM, Nieuwland G, van der Weele JA, Kok A (2000) Benthic-pelagic coupling in the oligotrophic Cretan Sea. Prog Oceanogr 46:457-480

Fontanier C, Jorissen FJ, Chaillou G, David C, Anschutz P, Lafon V (2003) Seasonal and interannual variability of benthic foraminiferal faunas at $550 \mathrm{~m}$ depth in the Bay of Biscay. Deep-Sea Res I 50:457-494

Furtado VV, Mahiques MM (1990) Distribuição de sedimentos em regiões costeiras e plataforma continental norte do Estado de São Paulo. In: Simpósio de Ecossistemas da Costa Sul e Sudeste Brasileira. Publ Ac Cienc Est S Paulo 71:20-29

Gonzalez-Rodriguez E (1991) A ressurgência de Cabo Frio (RJ, Brasil): fertilidade e fatores nutricionais limitantes da biomassa fitoplanctônica. Rev Brasil Biol 51:471-486

Gooday AJ, Turley CM (1990) Responses by benthic organisms to inputs of organic material to the ocean floor: a review. Phil Trans R Soc Lond A 331:119-138

Graf G (1989) Benthic-pelagic coupling in a deep-sea benthic community. Nature 341:437-439

Graf G (1992) Benthic-pelagic coupling: a benthic view. Oceanogr Mar Biol Annu Rev 30:149-190

Josefson AB, Forbes TL, Rosenberg R (2002) Fate of phytodetritus in marine sediments: functional importance of macrofaunal community. Mar Ecol Prog Ser 230:71-85

Karl DM (1980) Cellular nucleotide measurements and applications in microbial ecology. Microbiol Rev 44:739-796

Karl DM (1993) Total microbial biomass estimation derived from the measurement of particulate adenosine-5'-triphosphate. In: Kemp PF, Sherr BF, Sherr EB, Cole JJ (eds) Handbook of methods in aquatic microbial ecology. Lewis Publishers, Boca Raton, FL, p 359-368

Karl DM, Dobbs FC (1998) Molecular approaches to microbial biomass estimation in the sea. In: Cooksey KE (ed) Molecular approaches to the study of the ocean. Chapman \& Hall, London, p 29-89

Karl DM, Christian JR, Dore JE, Letelier RM (1996) Microbiological oceanography in the region west of the Antartica Peninsula: microbial dynamics, nitrogen cycle and carbon flux. In: Ross RM, Hoffman EE, Quetin LB (eds) Foundations for ecosystem research west of the Antartica Peninsula. Antarctic Research Series, Vol 70. American Geophysical Union, Washington, DC, p 303-332

Kiørboe T (2003) High turnover rates of copepods fecal pellets due to Noctiluca scintillans grazing. Mar Ecol Prog Ser 258:181-188

Köster M, Meyer-Reil L (2001) Characterization of carbon and microbial biomass pools in shallow water coastal sediments of the southern Baltic Sea (Nordrügensche Bodden). Mar Ecol Prog Ser 214:25-41

Lavaleye MSS, Duineveld GCA, Berghuis EM, Kok A, Witbaard R (2002) A comparison between the megafauna communities on the N.W. Iberian and Celtic continental margins - effects of coastal upwelling? Prog Oceanogr 52: 459-476

Lopes RM, Brandini F, Gaeta SA (1999) Distribution patterns of epipelagic copepods off Rio de Janeiro (SE Brazil) in summer 1991/1992 and winter 1992. Hydrobiologia 411: 161-174

Mahiques MM, Silveira ICA, Sousa SHM, Rodrigues M (2002) Post-LGM sedimentation on the outer shelf-upper slope of the northernmost part of the São Paulo Bight, southeastern Brazil. Mar Geol 181:387-400

Matsuura Y (1986) Contribuição ao estudo da estrutura oceanográfica da região sudeste entre Cabo Frio (RJ) e
Cabo de Santa Marta (SC). Cien e Cult 38:1439-1450

Miranda LB (1982) Análises de massas de água da plataforma continental e da região oceânica adjacente: Cabo de São Tomé (RJ) a Ilha de São Sebastião (SP). PhD thesis, University of São Paulo

Moser GAO, Gianesella-Galvão SMF (1997) Biological and oceanography upwelling indicators at Cabo Frio (RJ). Rev Bras Oceanogr 45:11-23

Pfannkuche O (1993) Benthic response to the sedimentation of particulate organic matter at the BIO-TRANS station, $47^{\circ} \mathrm{N}-20^{\circ} \mathrm{W}$. Deep-Sea Res II 40:135-150

Pfannkuche O, Sommer S, Kähler A (2000) Coupling between phytodetritus deposition and the small-sized biota in the deep Arabian Sea: analyses of biogenic sediment compounds. Deep-Sea Res II 47:2805-2833

Plante-Cuny MR (1978) Pigments photosynthétiques et production primaire des fonds meubles néritiques d'une région tropicale (Nosy-Bé, Madagascar). Trav Doc ORSTOM 96:1-359

Raghukumar C, Bharathi PAL, Ansari ZA, Nair S and 5 others (2001) Bacterial standing stock, meiofauna and sedimentnutrient characteristics: indicators of benthic disturbance in the Central Indian Basin. Deep-Sea Res II 48:3381-3399

Rudnick DT (1989) Time lags between the deposition and meiobenthic assimilation of phytodetritus. Mar Ecol Prog Ser 50:231-240

Siegel DA, Deuser WG (1997) Trajectories of sinking particles in the Sargasso Sea: modeling of statistical funnel above deep-ocean sediment traps. Deep-Sea Res I 44:1519-1541

Silveira ICA, Schmidt ACK, Campos EJD, Godoi SS, Ikeda Y (2000) A Corrente do Brasil ao Largo da Costa Leste Brasileira. Rev Bras Oceanogr 48(2):171-183

Soetaert K, Middelburg JJ, Herman PMJ, Buis K (2000) On the coupling of benthic and pelagic biogeochemical models. Earth-Sci Rev 51:173-201

Soltwedel T (1997) Temporal variabilities in benthic activity and biomass on the western European continental margin. Oceanologica Acta 20:871-879

Suess E (1980) Particulate organic carbon flux in the oceans surface productivity and oxygen utilization. Nature 288 : 260-263

Sumida PYG, Tyler PA, Lampitt RS, Gage JD (2000) Reproduction, dispersal and settlement of the bathyal ophiuroid Ophiocten gracilis in the NE Atlantic Ocean. Mar Biol 137: 623-630

Sun M, Aller RC, Lee C (1991) Early diagenesis of chlorophyll $a$ in Long Island Sound sediments: a measure of carbon flux and particle reworking. J Mar Res 49:379-401

Tyler PA (1988) Seasonality in the deep-sea. Oceanogr Mar Biol Annu Rev 26:227-258

Valentin J, Monteiro-Ribas WM (1993) Zooplankton community structure on the east-southeast Brazilian continental shelf (18-23ㅇ S latitude). Cont Shelf Res 13:407-424

Valentin J, Moreira AP (1978) A matéria orgânica de origem zooplanctônica nas águas de ressurgência de Cabo Frio (Brasil). An Acad Bras Cien 50:103-112

Valentin J, André DL, Jacob SA (1987) Hydrobiology in the Cabo Frio (Brazil) upwelling: 2-dimensional structure and variability during a wind cycle. Cont Shelf Res 7:77-88

Ventura CRR, Falcão APC, Santos JS, Fiori CS (1997) Reproductive cycle and feeding periodicity in the starfish Astropecten brasiliensis in the Cabo Frio upwelling ecosystem (Brazil). Invertebr Reprod Dev 31:135-141

Webb DG, Montagna PA (1993) Initial burial and subsequent degradation of sedimented phytoplankton: relative impact of macro- and meiobenthos. J Exp Mar Biol Ecol 166: 151-163

Submitted: May 3, 2004; Accepted: November 30, 2004

Proofs received from author(s): March 29, 2005 